\title{
Die Uitgebreide Rol van die Verpleegster
}

Gevolgtrekkings en aanbevelings tydens 'n werksgroepbespreking. gehou by die Universiteit van die itwatersrand. Johannesburg. van die 4de tot die 6de Augustus 1977.

Hierdie verslag is saamgestel deur:

Dr G.R. Beaton

Professor, Afdeling van Voortgesette Mediese Onderwys, Universiteit van die Witwatersrand, Johannesburg.

\section{Dr J. McMurdo}

Voorsitter van die Finale Voltallige vergadering van die Werksgroepbespreking.

\author{
Dr T.D. Wilson
}

Sameroeper van die Werksgroepbesprekings.

\section{Ms M.E. Conradie}

Senior Lektrise, Departement van Verpleegkunde. Verantwoordelik vir vertaling in Afrikaans.

\section{REDAKSIONELE KOMMENTAAR}

Hoewel die opskrif van die verslag lui "Die Uitgebreide Rol van die Verpleegster," moet die aandag daarop gevestig word dat die verpleegster se rol reeds lank al "uitgebrei" het. Die werksaamhede wat in die verslag beskryf word, is deur verpleegsters in mindere of meerdere mate by talle klinieke en hospitale in Suid-Afrika onderneem, soos trouens meer as 'n dekade lank oor die hele wêreld gebeur het.

\section{EDITORIAL COMMENT}

Although this report is published under the title "Die Uitgebreide Rol van die Verpleegster," attention should be drawn to the fact that the nurse's role has for a very long time been "extending." The activities described in this report have been undertaken by nurses to a greater or lesser degree in the numerous clinic services and in hospitals in South Africa, as has indeed been the case throughout the world, for over a century.

\section{SUMMARY}

There is need both for change in and extension of primary health care services in South Africa.

It is felt that nurses receive inadequate training, recognition and support in this area; that they lack legal and professional protection; and that there should be many more of them in this area. 


\section{INLEIDING}

D IE verpleegster speel ' $n$ baie belangrike rol in antwoord op die toenemende en veranderde behoeftes van die gesondheidsdienste in Suid-Afrika. Die middelpunt van belangstelling hedendaags is die sogenaande "uitgebreide" rol van die verpleegster' en in die besonder die poging om verpleegsters in die kliniese situasie te gebruik. 234

In Augustus 1977 het die Afdeling van Voortgesette Mediese Onderwys van die Universiteit van die Witwatersrand 'n werksgroepbespreking gereël om te bepaal wat verpleegsters bydra en behoort by te dra tot die primêre gesondheidsdienste in Suid-Afrika

Ongeveer 60 afgevaardigdes van Suid-Afrika, Transkei, Botswana, Swaziland. Rhodesië en Malawi het deelgeneem. Staatsgesondheidsdienste. Provinsiale en plaaslike owerhede. universiteite en stedelike en plattelandse dokters en verpleegsters was verteenwoordig.

Twee belangrike beperkings op die besprekingsgrense van die werksgroep is deur die afgevaardigdes aanvaar, naamlik: dat net die voorsiening van primêre gesondheidsorg bespreek sal word, en

dat net die rol van die verpleegster in die voorsiening van primêre gesondheidsorg bespreek sal word.

Binne die grense van die beperkings was daar ope bespreking wat georganiseer was om klem op die volgende areas te lê:

I. Wat verpleegsters alreeds in hulle uitgebreide rol op die gebied van primêre gesondheidsdienste lewer en watter probleme ondervind word;

2. Die metodes van opleiding, insluitende die konsepte van standardisasie (eenvormigheid) en indiensopleiding;

3. Die bevolkingsgroepe en gemeenskapsgroepe vir wie voorsiening gemaak word;

4. Die evaluering van die verpleegster en haar voortgesette onderrig;

5. Loopbaanstruktuur, erkenning, status en salarisse van verpleegsters in primêre gesondheidsdienste;

6. Gemeenskapsreaksie en betrokkenheid ten opsigte van primêre gesondheidsdienste insluitende gemeenskapsopvoeding.

Tydens die finale volle sitting van die werksgroepbespreking is sekere algemene gevolgtrekkings gemaak, probleme is geidentifiseer en aanbevelings ten opsigte van daadwerklike optrede is gemaak. Die afgevaardigdes het oor hierdie sake almal saamgestem. Terwyl ons gepoog het om hierdie konsensus so noukeurig as moontlik weer te gee, neem die persone verantwoordelikheid vir die samestelling van hierdie verslag asook die verantwoordelikheid vir die finale bewoording.
Die verslag is in twee dele verdecl:

1. Algemene gevolgtrekkings

2. Probleme geidentifiseer.

\section{ALGEMENE GEVOLGTREKKINGS}

Daar is ' $n$ behoefte alan beide verandering en uitbreiding van die primêre gesondheidsdienste in Suid-Afrika.

Baie verpleegsters verleen alreeds hulp aan dokters in die voorsiening van primêre gesondheidsdienste. In die meeste areas is hulle werk egter beperk en word dit minder doeltreffend gemaak deur vier belangrike faktore:

(a) hulle kry nie genoeg opleiding nie:

(b) hulle word nie erkenning verleen nie;

(c) hulle kry nie ondersteuning, toesig en rigtingsaanwysing nie;

(d) hulle geniet nie wetlike en professionele beskerming nie.

Verder is daar " $n$ behoefte aan baie meer verpleegsters in hierdie gebied as wat daar op die oomblik in diens is.

Alle range van verpleegsters het die vermoë om primêre gesondheidsorg te voorsien. Hierdie punt word nie genoegsaam ingesien nie. Plaaslike omstandighede, die gemeenskapsgroep wat van die diens voorsien moet word asook die beskikbaarheid van verpleegsters. bepaal die keuse van welke rang. hetsy geregistreerde verpleegsters, ingeskrewe verpleegsters of verpleegassistente (die huidige terminologie in die Republiek van Suid-Afrika). opgelei moet word om primêre gesondheidsorg te voorsien.

Alhoewel verpleegsters primêre gesondheidsdienste van uitstaande gehalte kan lewer en wel lewer, kan hulle dit nie in afsondering doen nie. Dokters is noodsaaklik vir opleidingsdoeleindes. toesig en ondersteuning van verpleegsters in primêre gesondheidsdienste. Dokters en verpleegsters behoort saam te werk in die veld, tydens voor-registrasie-opleiding, gesondheidsorgverskaffing en deelname in voortgesette onderwys.

Sekere kennis is noodsaaklik vir alle verpleegsters wat primêre gesondheidsorg verskaf. Dit kan die basis vorm vir die minimum standaard in die sub-kontinent. Verskillende minimum standaarde kan waarskynlik vir verskillende range van verpleegsters vasgestel word

Voortgesette onderwys, indiensopleiding en 'n realistiese loopbaanstruktuur is almal belangrike aspekte ten opsigte van die voorsiening van affektiewe primêre gesondheidsdienste, en om te verseker dat die primêre gesondheidsverpleegster genoegsame werksbevrediging ervaar.

Evaluering van alle aspekte van die voorsiening van gesondheidsdienste is noodsaaklik. Hierdie evaluering geskied nie tans in genoegsame mate nie en word ook nie genoegsaam uitgevoer nie. 
Verpleegsters wat in die primêre gesondheidsdienste werksaam is. hulle toesighouers en onderwysers, en die kwaliteit van die gesondheidsdienste wat gelewer word. moet voortdurend ge-evalueer word. Hierdie evaluering behoort deur die verpleegsters self (self-evaluering en groepevaluering). deur onderwysers (en t.a.v. onderwysers deur verpleegsters) deur die gemeenskap gedoen te word asook deur epidemioloë deur gebruik te maak van gesondheidsstatistieke.

Klem is gelê op die feit dat toepaslike gesondheidsstatistiek ten opsigte van morbiditeit en mortaliteit nie beskikbaar is in baie areas nie en veral nie in die onderontwikkelde en plattelandse gebiede nie.

\section{IDENTIFISERING VAN PROBLEME}

Erkenning van die primêre gesondheidsverpleegster;

Wetlike en administratiewe probleme;

Verspreiding van gesondheidsmannekrag;

Keuring;

Opleiding;

Loopbaanstruktuur.

\section{Erkenning van die primêre gesondheidsverpleegster: Deur die mediese beroep.}

Dokters, mediese studente, mediese skole en statutêre mediese owerhede moet almal nog oorreed word dat verpleegsters ' $n$ belangrike rol te vervul het in die voorsiening van primêre gesondheidsdienste. Hulle moet sommige van hulle tradisionele idees wysig en hulle moet die beginsels van spanwerk en delegasie aanvaar; asook die rol van onderwysers wat omsien na sowel die basiese opleiding as die voortgesette onderwys van verpleegsters. Hulle moet ook berus by enige moontlike finansiële verlies wat as gevolg van die verpleegsters wat in die primêre gesondheidsdienste werksaam is, ontstaan.

\section{Deur ander verpleegsters}

Beide senior en junior verpleegsters benodig 'n duideliker beeld van die rol van die primêre gesondheidsverpleegster en sal ook sommige van hulle tradisionele idees moet verander. Daar is ' $n$ behoefte aan duidelike rolbeskrywing, verantwoordelikhede en bestuurslyne sodat probleme soos belangebotsings en jaloesie, vermy kan word.

\section{Deur ander gesondheidswerkers}

Verwante gesondheidswerkers soos byvoorbeeld fisioterapeute, radiografiste, laboratoriumtegnici, aptekers, sosiale werksters en andere moet almal oortuig word van die rol van die verpleegster in die primêre gesondheidsdienste.

Daar moet 'n duidelike omskrywing wees van welke ondersoeke en behandelings deur die primêre gesondheidsverpleegster onderneem en aangevra mag word.

\section{Deur pasiënte en die gemeenskap}

Dit blyk asof primêre gesondheidsverpleegsters deur meeste gemeenskapsgroepe aanvaar word, maar in sommige was daar wel probleme ten opsigte van aanvaarding. Deelname van die gemeenskap aan die beplanning van gesondheidsdienste asook ware gemeenskapsbetrokkenheid in die voorsiening en verskaffing van gesondheidsdienste is ongewoon in Suider-Afrika. Dit is dringend noodsaaklik dat die gemeenskap geraadpleeg moet word oor alle aspekte van gesondheidsdienste. insluitende die rol van die primêre gesondheidsverpleegster. Gemeenskapsbetrokkenheid behoort die stigting van kliniekkomitees en verbeterde gebruik van vrywillige organisasies in te sluit.

\section{Wetlike en Administratiewe Probleme: Die Voorskryf van Medisyne}

Al die afgevaardigdes was dit eens dat daar belangrike wetlike versperrings in die Republiek van Suid-Afrika is wat verpleegsters verhoed om medisyne met betrekking tot hulle primêre gesondheidsfunksie voor te skryf. Alhoewel daar in sommige situasies 'n uitweg gevind is, is daar nogtans 'n dringende behoefte aan wetlike verandering.

Die aanvraag-ondersoeke en paramediese dienste

Die uitreiking van siektesertifikate.

Die fragmentering van werkgewers van primêre gesondheidsverpleegsters:

Die bestaande fragmentering van die beheer van gesondheidsdienste tussen die Staat, Provinsiale en plaaslike owerhede in Suid-Afrika veroorsaak probleme. Die hoop word uitgespreek dat die nuwe Wet op Gesondheid (1977) baie van hierdie probleme uit die weg sal ruim.

\section{Fragmentering van statutêre mediese- en verplegings- beheerliggaam.}

Die Rhodesiese afgevaardigdes het verslag gedoen dat hulle gesondheidswerkers almal deur een statutêre liggaam beheer word. Samewerking en bevordering van gesondheidsorg word hierdeur vergemaklik. Die aparte Mediese- en Verpleegstersrade in Suid-Afrika skyn samewerking en ontwikkeling te strem.

\section{Beskerming en indemniteit}

Ernstige kommer is deur alle afgevaardigdes uitgespreek oor die behoefte om duidelikheid te verkry oor, en die probleem van beskerming en professionele indemniteit vir verpleegsters wat primêre gesondheidsdienste verskaf, op te los.

\section{Verspreiding van Gesondheidsmannekrag}

Werwing van primêre gesondheidsverpleegsters kan hospitaalpersoneel uitdun en die gevaar van die ontstaan van 'n kettingreaksie is beklemtoon. Indien 'n groter aantal verpleegsters vir primêre gesondheidsdienste benodig word, moet daar aandag gegee word aan algehele verbeterde werwing van verpleegsters. 
Die feil dat ingeskrewe verpleegsters en ingeskrewe verpleegassistente tot in uiters beperkte mite gebruik word in die voorsiening van primêre gesondheidsdienste, is beklemtoon.

Die wanverspreiding van gesondheidswerkers in stedelike en plattelandse gebiede is "n groot probleem dwarsoor die wêreld. Die probleem is veral akuut in Suider-Afrika.

Alhoewel die rol van die verpleegsters in die voorsiening van kuratiewe primêre gesondheidsdienste beklemtoon is. is dit deur die werksgroep belangrik geag daarop te wys dat daar "n toepaslike balans moet wees tussen kuratiewe en voorkomende gesondheidsdienste, en gesondheidsvoorligting.

\section{Probleme ten opsigte van keuring}

Primêre gesondheidsververpleegsters moet betrokke wees in die gemeenskap waar hulle werk. Hulle moet dus sovêr moontlik gekeur word uit daardie gemeenskap. Hulle moet ook gekeur word met die doel om in daardie gemeenskap werksaam te wees en dit sal ideaal wees as die gemeenskap deelname kan hê aan hulle keuring.

\section{Probleme met opleiding Basiese verplegingsopleiding}

Hersiening van basiese opleiding is sonder twy fel nodig. Meer klem moet op primêre gesondheidsorg geplaas word in die opleiding van geregistreerde-, ingeskrewe- en assistentverpleegsters. Die meeste afgevaardigdes was dit eens oor die feit dat primêre gesondheidsorg op beide basiese en nabasiese vlakke ingesluit moet word, terwyl ander weer gevoel het dat die opleiding net op basiese vlak gegee moet word. Die feit dat beheerliggame nie nuwe kursusse behoort in te stel voordat bestaande kursusse herevalueer was nie, is beklemtoon.

\section{Kraamopleiding}

Alhoewel daar geen struikelblokke is met betrekking tot die opleiding van genoegsame aantalle ingeskrewe verpleegsters in kraamverpleging nie, geskied dit nie tans nie. Bekwaamheid in kraamverpleging is gewoonlik 'n vereiste vir die primêre gesondheidsverpleegster in die plattelandse gebiede. Groter aantalle ingeskrewe verpleegsters behoort dus aangemoedig te word om hulle te bekwaam in kraamverpleging.

\section{Primêre gesondheidsorgopleiding}

Desentralisasie is hier sover as moontlik noodsatklik Gesondheidsorgwerkers moet opgelei word in die omstandighede waarin hulle verwag word om te werk. Die atmosfeer van gesofistikeerde akidemiese hospitale wat op hö̈ vlak tegniese, sekondêre en tersiêre sorg voorsien, moet vermy word. Primêre gesondheidsverpleegsters moet opgelei word so na as moontlik aan die gemeenskap wat hulle moet dien en versorg.

\section{Voortgesette onderwys en ondersteuning}

Effektiewe primêre gesondheidsorg kan nie in afsondering voorsien word nie. Dit is dus noodsaaklik dat primére gesondheidsverpleegsters voortgesette onderwys ontvang asook ondersteuning in die vorm van gereelde bespreking met mekaar. met die dokters na wie hulle pasiente verwys en met hulle onderwysers. Erkenning hiervan is egter noodsaaklik deur die werkgewers sodat tyd en fasiliteite veskikbaar gestel kan word.

\section{Probleme met Loopbaanstruktuur}

Loopbaanstruktuur is deur die besprekingsgroep beklemtoon vir verpleegsters werksaam in alle kliniese gebiede. Dit is beklemtoon dat $n$ uitstaande kliniese verpleegster nie uit die kliniese omgewing na administratiewe dienste geneem behoort te word nie. maar dat sy eerder die geleentheid gegee moet word om op kliniese gebied vooruit te gaan.

\section{Gemeenskapsbetrokkenheid}

Daar is nie genoegsame gemeenskapsbetrokkenheid by die neem van besluite ten opsigte van gesondheidsorg, die daarstelling van gesondheidsorg en evaluering van gesondheictsorg nie. Verhoogde gemeenskapsbetrokkenheid moet aangemoedig word.

\section{VERWYSINGS:}

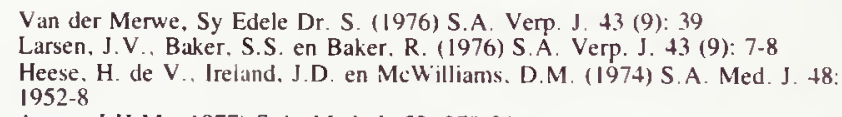

